\title{
ANALISIS JARINGAN DAN PEMELIHARAAN PADA JARINGAN DISTRIBUSI DI PT.PLN WILAYAH CABANG PINRANG
}

\author{
Rizal A Duyo ${ }^{1}$, Andi Sulkifli ${ }^{2}$ \\ 1,2 Jurusan Elektro Fakultas Teknik, Universitas Muhammadiyah Makassar \\ e-mail: rizal.a@unismuh.ac.id ${ }^{1}$, andi_sulkifli@ymail.com ${ }^{2}$
}

\begin{abstract}
Used in electrical energy distribution effort to the community. Know the factors that affect the capacity of power distribution transformers for 3 phase and 1 phase and to know system maintenance performed on the distribution network and transformer at. PLN ( Persero ) Branch Pinrang. All data that is required in this study was obtained through several instruments such as surveys or direct observation, interviews, and a review of literature used to complement and meet the required data. All data were collected and analyzed using descriptive analysis. These results prove that the distribution network is used on the PT . PLN (Persero ) Branch Pinrang consists of a primary distribution channels, distribution transformers and secondary distribution channels. This distribution network is used to distribute electrical energy to the entire community of Pinrang. Kapasitas of a distribution transformer for 3 phases and the first phase is determined by the amount of load that is served is added to the burden of the future development. System maintenance is performed on the distribution network and transformer at. PLN ( Persero ) Branch Pinrang done regularly and proactively with emphasis on preventive measures aiming to prevent disturbance of the action reprensif in overcoming the disorder.
\end{abstract}

Intisari- System jaringan distribusi yang ada di PT. PLN (Persero) Cabang Pinrang yang digunakan dalam upaya pendistribusian energi listrik kemasyarakat, mengetahui faktor-faktor yang mempengaruhi kapasitas daya transformator distribusi untuk 3 fase dan 1 fase dan untuk mengetahui system pemeliharaan yang dilakukan pada jaringan distribusi dan transformator pada PT. PLN (Persero) Cabang Pinrang. Seluruh data yang diperlukan dalam penelitian ini diperoleh melalui beberapa instrument berupa survey atau pengamatan langsung, wawancara, dan studi literatur yang digunakan untuk melengkapi dan memenuhi data yang dibutuhkan.Seluruh data yang terkumpul kemudian di analisis dengan menggunakan analisis deskriptif.Hasil penelitian ini membuktikan bahwa jaringan distribusi yang digunakan pada PT. PLN (Persero) Cabang Pinrang terdiri dari saluran distribusi primer, transformator distribusi dan saluran distribusi sekunder.Jaringan distribusi ini digunakan untuk mendistribusikan energy listrik keseluruh masyarakat Kabupaten Pinrang.Kapasitas dari suatu transformator distribusi untuk 3 fase dan 1 fase ditentukan oleh jumlah beban yang dilayani ditambahkan dengan perkembangan beban dikemudian hari.Sistem pemeliharaan yang dilakukan pada Jaringan distribusi dan transformator pada PT. PLN (Persero) Cabang Pinrang dilakukan secara rutin dan proaktif dengan mengutamakan tindakan preventif yang bertujuan untuk mencegah terjadinya gangguan dari pada tindakan reprensif dalam mengatasi terjadinya gangguan.

Kata Kunci- Distribusi, Fase, Transformator, Survey, Deskriptif 


\section{PENDAHULUAN}

\section{Latar Belakang Masalah}

Seiring dengan meningkatnya ilmu pengetahuan dan teknologi dewasa ini menyebabkan tingginya kebutuhan akan pemanfaatan energi di berbagai aspek kehidupan. Salah satu sumber energi yang paling banyak digunakan hingga saat ini adalah sumber energi listrik. Energi listrik mempunyai banyak keunggulan dibandingkan sumber energi lainnya, karena sifatnya yang fleksibel dan mudah dikonversi dari sumber energi lain, demikian juga sebaliknya. Hal inilah yang menyebabkan energi listrik merupakan salah satu pilihan utama pemakai energi. Tingginya kebutuhan akan tenaga listrik tersebut, maka dibutuhkan pula suatu sistem yang dapat mengelola energi listrik yang ada saat ini agar energi listrik tersebut dapat disumberdayakan guna memenuhi kebutuhan masyarakat akan energi listrik saat ini maupun di masa yang akan datang. Oleh karena itu, diperlukan suatu perencanaan yang teliti, terperinci dan sistematis dalam perencanaan sistem tenaga listrik seperti desain sistem pembangkit, jaringan transmisi dan sistem jaringan distribusinya. Perencanaan tersebut juga harus memperhatikan beberapa aspek lain yang disesuaikan dengan perkembangan sistem daya/beban yang disesuaikan dengan pengaruhnya dari segi sosial dan ekonomi. Salah satu bagian dari sistem tenaga listrik yang menyalurkan energi listrik dari pusat pembangkitan sampai kekonsumen atau pelanggan adalah Sistem distribusi mempunyai fungsi yang penting sebagai komponen dari sistem tenaga listrik khususnya dalam penyaluran tenaga listrik ke konsumen maka perlu dilakukan suatu studi sebagai salah satu upaya memaksimalkan pemenuhan kebutuhan energi listrik terhadap konsumen yakni (masyarakat).

\section{Rumusan Masalah}

1) Bagaimanakah sistem jaringan distribusi yang ada di PT. PLN (Persero) Cabang Pinrang yang digunakan dalam upaya pendistribusian energi listrik ke masyarakat?
2) Bagaimanakah faktor-faktor yang mempengaruhi kapasitas daya transformator distribusi untuk 3 fase dan 1 fase?

3) Bagaimanakah sistem pemeliharaan yang dilakukan pada jaringan distribusi dan trasformator pada PT. PLN (Persero) Cabang Pinrang?

\section{Tujuan Penelitian}

1) Untuk mengetahui sistem jaringan distribusi yang ada di PT. PLN (Persero) Cabang Pinrang yang digunakan dalam upaya pendistribusian energi listrik ke masyarakat.

2) Untuk mengetahui faktor-faktor yang mempengaruhi kapasitas daya transformator distribusi untuk 3 fase dan 1 fase.

3) Untuk mengetahui sistem pemeliharaan yang dilakukan pada jaringan distribusi dan transformator pada PT. PLN (Persero) Cabang Pinrang.

\section{Batasan Masalah}

Studi jaringan distribusi pada PT. PLN (Persero) Cabang Pinrang difokuskan pada daerah Pinrang Kota, meliputi :

(a) Analisa terhadap hasil pengukuran triwulan (3 bulan) pada gardu distribusi pada bulan September 2014.

(b) Sistem pemeliharaan terhadap transformator dan jaringan distribusi yang digunakan.

\section{TINJAUAN PUSTAKA}

\section{Jaringan Distribusi}

\section{Gambaran Umum}

Secara garis besar sistem tenaga listrik terbagi atas tiga komponen utama, yaitu bagian pembangkit, bagian transmisi, dan bagian distribusi.

PT. PLN (Persero) Cabang Pinrang merupakan salah satu bagian dari PT. PLN (Persero) Wilayah SULSELRA yang membawahi beberapa unit ranting yang tersebar di 4 (empat) kabupaten yaitu Kabupaten Pinrang, Kabupaten Polewali Mamasa (POLMAS), Kabupaten Majene dan Kabupaten Mamuju. PT. PLN (Persero) Cabang Pinrang terdiri dari 3 gardu induk. Namun, studi yang dilakukan hanya diprioritaskan pada gardu induk Pinrang, yang melayani 6 feeder, yaitu Fl 
Langnga, F2 Kariango, F3 Tiroang, F4 lasinrang, F5 Jampue dan F6 Polewali.Bagian distribusi merupakan bagian yang mendistribusikan daya listrik ke tiap-tiap beban.Bagian ini dimulai dari gardu induk distribusi.Pada gardu induk distribusi, tingkat tegangan subtransmisi diturunkan menjadi tingkat tegangan distribusi primer dengan harga berkisar antara $6 \mathrm{kV}$ sampai 30 kV.Tegangan distribusi standar PLN adalah 20 $\mathrm{kV}$. Dari gardu induk distribusi daya listrik disalurkan melalui jaringan distribusi primer ke gardu distribusi yang selanjutnya tingkat tegangan distribusi primer diturunkan menjadi tingkat tegangan distribusi sekunder dengan harga berkisar antara $127 \mathrm{~V}$ sampai $380 \mathrm{~V}$. Tegangan standar distribusi sekunder PLN adalah 220/380 V. Dari gardu distribusi selanjutnya daya listrik didistribusikan kepada konsumen tegangan rendah. Disamping konsumen tegangan rendah terdapat juga konsumen tegangan menengah yaitu $20 \mathrm{kV}$ dan konsumen tegangan tinggi adalah $150 \mathrm{kV}$,

\section{Jaringan Distribusi}

Jaringan distribusi adalah suatu sistem jaringan yang berfungsi untuk menyalurkan energi listrik dari pusat listrik hingga sampai ke rumah-rumah dan konsumen - konsumen kecil lainnya (pelanggan).

Jaringan distribusi berawal dari sisi sekunder transformator daya digardu induk (GI) penerima dan kemudian melalui saluran tegangan menengah.

Bentuk jaringan distribusi dapat dilihat pada gambar di bawah ini :

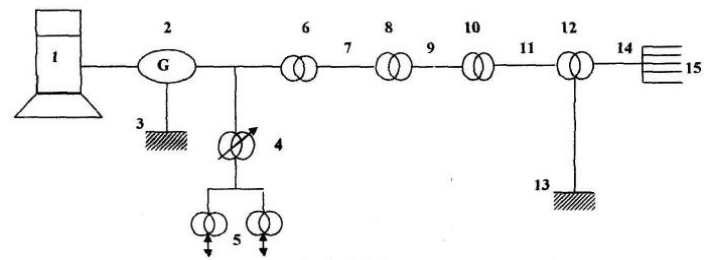

Gambar 1. Sistem jaringan Distribusi( (1) mesin penggerak mula, (2) generator tiga fasa $50 \mathrm{hz}$ (pembangkit), (3) pertahanan netral, (4) Step down trafo pemakaian sendiri, (5) Pemakaian sendiri pada pusat pembangkit, (6) Gardu induk (GI) pusat pembangkit dengan transformator step UP ,10/150 KV, (7) Saluran transmisi dengan saluran ganda pada tegangan $150 \mathrm{KV}$, (8) Gardu induk pusat beban dengan trafo step down 150/70 KV, (9) Saluran sub transmisi 30 - $70 \mathrm{KV}$, (10)
Gardu hubung dengan trafo step down 70/20 KV, (11) Saluran distribusi primer (saluran tegangan menengah) pada $20 \mathrm{KV}$,(12) Gardu distribusi primer trafo step down $20 \mathrm{KV} / 380 \mathrm{~V}$ antar fasa dan $220 \mathrm{~V}$ fasa- netral, (13) Pentanahan netral, (14) Saluran distribusi sekunder pada tegangan 380/220 V, (15) Beban / konsumen).

Jaringan distribusi merupakan salah satu komponen primer yang perlu mendapat perhatian dan Jaringan distribusi berfungsi untuk menyalurkan tenaga listrik (energi listrik) dari gardu induk ke gardu distribusi dan mendistribusikan tenaga listrik tersebut ke beban.Jaringan distribusi primer yang bertegangan menengah berfungsi untuk menyalurkan daya listrik dari gardu induk ke transformator distribusi yang terhubung ke beban industri.pemeliharaan yang kontinu. Oleh karena itu, dibutuhkan perencanaan pengembangan optimum jaringan distribusi. Perencanaan ini harus mengikuti peraturanperaturan yang berlaku pada penyelenggara sistem yaitu PLN. Jadi standarisasi yang digunakan PT. PLN (Persero) menjadi standar pokok yang selalu diutamakan dalam perencanaan jaringan distribusi sehingga menghasilkan perencanaan yang menguntungkan dari segi biaya dan memadai dari segi teknis,

Secara umum komponen-komponen jaringan distribusi terdiri dari tiga bagian, yaitu :

a) Saluran distribusi primer

b) Transformator distribusi

c) Saluran distribusi sekunder

\section{Saluran Distribusi Primer}

Pada jaringan distribusi primer ada beberapa bentuk struktur dari sistem. Bentuk-bentuk dari jaringan distribusi primer ini tergantung dari jenis lokasi akan dipasang dan sesuai dengan kebutuhan. Dalam pemilihan bentuk jaringan distribusi ada beberapa faktor yang perlu dipertimbangkan, yaitu jenis beban (beban domestik, beban komersial atau beban industri), daerah (kota atau desa), kepadatan beban, faktor keindahan dan keamanan. Berdasarkan hal-hal tersebut, maka timbul batasan-batasan dalam menentukan bentuk jaringan distribusi, yaitu :

1) Jatuh tegangan 
Jatuh tegangan antara titik awal dan titik akhir pada jaringan distribusi tidak boleh terlampau besar.

2) Keandalan pelayanan

Gangguan pada jaringan tidak boleh terlampau sering dan lama, sehingga kelangsungan pelayanan tetap terjag

3) Fleksibilitas Jaringan

Sistem jaringan distribusi mudah disesuaikan dengan perkembangan beban.

4) Biaya

Biaya investasi jaringan tidak boleh terlampau mahal.

Secara umum, peralatan-peralatan yang sering ditemukan pada gardu distribusi, antara lain (PLN Diklat Makassar, 2000) :

1) Isolating switch (saklar pemisah), gunanya untuk menghubungkan kabel yang dating dari arah gardu induk (incoming cable) ke rel utama pada gardu tersebut

2) Loadbreak switch (saklar beban), berfungsi untuk menghubungkan rel utama gardu distribusi dengan kabel keluar (outgoing cable) menuju ke arah gardu hubung.

3) Trafo distribusi yang dihubungkan melalui suatu saklar pemisahke rel utama yang diamankan oleh sebuah sekering.

Adapun jenis-jenis gardu distribusi dapat digolongkan menurut jenis pasangan dan jenis konstruksinya. Menurut jenis pasangannya gardu distribusi dibagi dalam :

(a) Pasangan dalam yaitu dimana semua peralatan utamanya ditempatkan dalam ruang tertutup.

(b) Pasangan luar, yaitu gardu distribusi yang semua peralatan utama sisi tegangan menengah dan transformator distribusi ditempatkan pada ruang terbuka, namun sebagian peralatan penghubung dan pengaman masih ditempatkan dalam ruangan tertutup.

Menurut konstruksinya gardu distribusi dapat dikelompokkan, sebagai berikut :

1) Gardu distribusi jenis besi (metal eland)

Gardu distribusi ini dibangun dalam suatu peti besi (metal eland) dimana transformator distribusi ditempatkan pada suatu bagian peti logam yang didudukkan di atas pondasi beton dengan kapasitas sampai 630 KVA. Begitu juga halnya dengan peralatan utama lainnya ditempatkan dalam box metal.

2) Gardu distribusi jenis mobil.

Gardu distribusi jenis mobil dibangun di atas sebuah kereta hela (trailer) atau semacam truk dan dapat berpindah-pindah. Gardu jenis ini digunakan pada lokasi yang mengalami gangguan layanan beban dari gardu distribusi jenis lain. Gardu ini digunakan untuk pemakaian sementara atau untuk memenuhi kebutuhan tenaga listrik dalam keadaan darurat.

3) Gardu distribusi jenis tiang

Gardu distribusi jenis tiang adalah gardu distribusi yang dibangun dengan menggunakan tiang sebagai penyangga bagiperalatan-peralatan utama gardu dengan kapasitas kecil sampaikurang dari 200 KVA. Ada beberapa macam struktur jaringan distribusi primer yang digunakan pada sustu sistem distribusi, yaitu :.

1) Struktur Radial

Struktur radial merupakan struktur yang paling sederhana dan jenis struktur yang ada.Bentuknya ditandai dengan penyulang utama yang keluar dari gardu induk dan bercabang-cabang menyerupai pohon, karena strukturnya yang sederhana maka biaya konstruksi dan operasi lebih murah. Akan tetapi keandalannya kurang baik, karena hanya dihubungkan pada suatu sumber melalui satu jalan saja. Sehingga bila ada gangguan pada penyulang utama dekat gardu induk maka pelayanan daya secara keseluruhan akan terputus. Kemudian tidak dapat melayani daerah yang sangat luas atau terlalu jauh sebab makin luas daerah yang dilayani oleh struktur ini semakin besar jatuh tegangan.

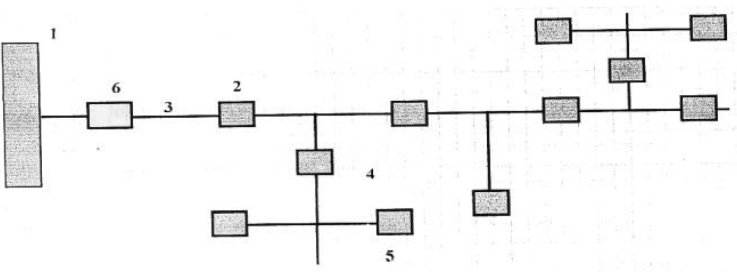

Gambar 2 Struktur Radial ( (1) Gardu induk distribusi, (2) Gardu distribusi, (3) Penyulang utama, 
(4) Penyulang lateral, (5) Penyuiang sub lateral, (6) Pemutus tenaga).

a) Struktur Loop (Ring)

Struktur loop ini membentuk suatu jaringan tertutup yang dimulai dari gardu induk melalui daerah-daerah beban dan kembali lagi ke gardu induk yang sama. Struktur ini merupakan pengembangan dari bentuk radial, yang mana pada operasinya dapat bekerja sebagai sistem radial biasa yang saklar dayanya dalam keadaan terbuka. Jika terjadi gangguan, maka bagian jaringan yang mengalami gangguan akan diisolir, kemudian saklar daya tertutup yang tenaga listriknya tetap dapat disalurkan, Dengan demikian nampak bahwa keandalannya lebih baik dibandingkan dengan sistem radial dan Struktur ini sering dipakai pada daerah pusat penduduk yang lokasinya menyerupai bentuk loop. Struktur loop ini lebih mahal karena kapasitas dari konduktor yang digunakan harus sanggup untuk menanggung beban secara keseluruhan jika salah satu penyulang yang dekat gardu induk mengalami gangguan. Bentuk struktur loop ini dapat dilihat pada gambar di bawah ini :

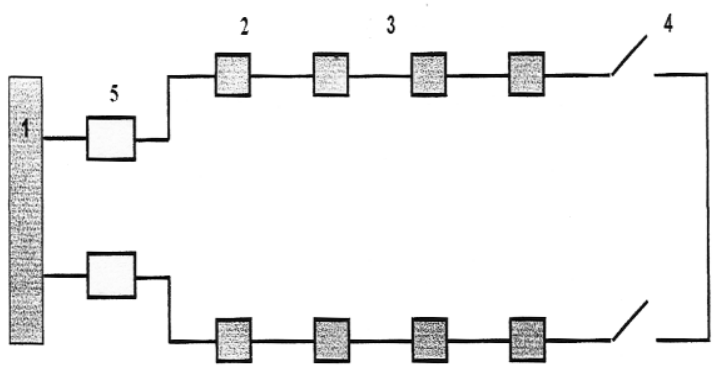

Gambar 3 Struktur Loop ( (1) Garduk induk distribusi, (2) Gardu distribusi, (3) Penyulang, (4) Saklar daya, (5) Pemutus daya).

b) Struktur Spindel

Struktur spindel merupakan pengembangan dari Struktur loop. Spindel berarti gelondong atau kumparan.Struktur spindel adalah suatu pola jaringan khusus yang ditandai dengan ciri adanya sejumlah kabel yang keluar dari suatu gardu induk (outging cable) menuju ke arah suatu titik temu yang disebut gardu hubung. Struktur ini memiliki sebuah penyulang cadangan dan sejumlah penyulang yang ditempati oleh gardu-gardu distribusi yang disebut sebagai penyulang kerja.

Pada struktur ini, jika terjaga gangguan pada salah satu penyulang kerja maka terlebih dahulu gangguan diisolir Kemudian saklar dayadi gardu hubung yang terhubung ke penyulang tersebut tertutup. Sehingga daya listrik disalurkan melaiui penyulang cadangan. Bentuk struktur sipndel ini dapat dilihat pada gambar di bawah ini :

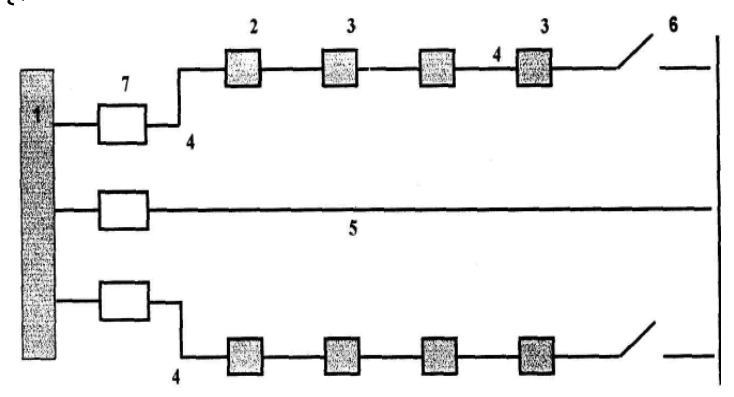

Gambar 4 Struktur Spindel ( (1) Gardu induk distribusi, (2) Gardu distribusi, (3) Gardu penghubung,

(4) Penyulang kerja, (5) Penyulang cadangan, (6) Saklar daya, (7) Pemutus daya).

\section{Transformator Distribusi}

Transformator distribusi adalah suatu transformator yang berfungsi menerima tegangan dari jaringan distribusi primer yang bertegangan menengah dan menurunkan tegangan tersebut ke tingkattegangan rendah, yaitu 220/380 Volt. Ada beberapa hal yang perlu diperhatikan dalam transformator distribusi, yaitu :

a) Jumlah phasa

Berdasarkan jumlah phasanya

transformator.

b) Tegangan nominal

Tegangan nominal adalah tegangan kerja yang mendasari perencanaan dan pembuatan instalasi serta peralatan listrik.

c) Daya nominal

Daya nominal adalah daya yang mendasari pembuatan dari peralatan listrik. Berdasarkan daya nominalnya dapat dikelompokkan transformator distribusi sebagai berikut yaitu $50 \mathrm{kVA}, 75 \mathrm{kVA}, 100 \mathrm{kVA}, 125 \mathrm{kVA}, 160$ kVA, $200 \mathrm{kVA}, 250 \mathrm{kVA}, 315 \mathrm{kVA}, 400$ kVA, $500 \mathrm{kVA}, 630 \mathrm{kVA}, 800 \mathrm{kVA}, 1000$ kVA, $1250 \mathrm{kVA}$, dan $1600 \mathrm{kVA}$.

Kapasitas dan suatu transformator distribusi untuk 3 fasa ditentukan oleh jumlah 
maksimum beban yang dilayani (daya yang terpasang) ditambahkan dengan perkembangan beban dikemudian hari (cadangan). Terlebih dahulu menghitung daya $(\mathrm{P})$ setiap fasanya, yang dirumuskan sebagai berikut:

$$
\begin{aligned}
& \mathrm{P}_{\mathrm{R}}=\mathrm{VN} \times \mathrm{I}_{\mathrm{R}} \\
& \mathrm{P}_{\mathrm{s}}=\mathrm{VN} \times \mathrm{I}_{\mathrm{S}} \\
& \mathrm{PT}=\mathrm{VN} \times \mathrm{I}_{\mathrm{T}}
\end{aligned}
$$

Kemudian hasilnya dijumlahkan, rumusnya adalah:

$$
\mathrm{P}_{\text {tot } 3 \phi}=\mathrm{P}_{\mathrm{R}}+\mathrm{P}_{\mathrm{S}}+\mathrm{P}_{\mathrm{T}}
$$

Dan hasilnya itu akan dijumlahkan dengan kapasitas trafo, yang dirumuskan sebagai berikut :

Kapasitas trafo $=\Sigma$ Daya terpasang $+30 \%$ dari Daya terpasang.

Sedangkan kapasitas dari suatu transformator distribusi untuk 1 fasa ditentukan oleh jumlah maksimum beban yang dilayani (daya yang terpasang) ditambahkan dengan perkembangan beban dikemudian hari (cadangan).Tetapi sebelumnya, terlebih dahulu menghitung daya yang terpasang $(\mathrm{P})$.

$$
\mathrm{P}=1 \times \mathrm{V}
$$

Dari hasilnya itu akan dijumlahkan. Dengan kapasitas trafo yang dirumuskan sebagai berikut:

Kapasitas trafo $=\Sigma$ Daya terpasang $+30 \%$ dari Daya terpasang

Dan rumus untuk menentukan daya trafo untuk 3 fasa dan untuk 1 fasa adalah sebagai berikut :

1) Untuk 3 fasa : $\mathrm{P}=\sqrt{3} \times \mathrm{V} \times \mathrm{I} \times \operatorname{Cos} \varphi$

2) Untuk 1 fasa $\mathrm{P}=\mathrm{V} \times \mathrm{I} \times \operatorname{Cos} \varphi$

Transformator merupakan salah satu material/peralatan yang paling penting untuk pemindahan dan pembagian tenaga listrik secara praktis, efektif dan ekonomis dalam lapangan yang luas. Kerugian yang terjadi dalam transformator pada muatan normal adalah kecil. Ada 2 macam kerugian yang terpenting di dalam trafo, yaitu (PLN Diklat Makassar, 2000):

1) Kerugian tembaga (kerugian watt $\mathrm{Cu}$ ).
Besarnya kerugian tembaga tergantung dari besarnya muatan pada transformator.

2) Kerugian besi (kerugian $\mathrm{Fe}$ )

Besarnya kerugian $\mathrm{Fe}$ adalah tetap meskipun transformator dihubungkan dan dimuati secara terus menerus pada siang dan malam.

Hal-hal yang perlu diadakan penelitian sebelum pemasangan trafo pada jaring-jaring yang bertegangan, yaitu :

a) Sifat-sifat dari transformator apakah sesuai jaringan yang ada atau tidak.

b) Kondisi trafo tersebut apakah masih dalam keadaan baik atau tidak.

c) Peralatan pengaman (bila ada) apakah masih dalam keadaan baik atau tidak.

Secara garis besar bentuk pemasangan transformator distribusi terbagi atas 2, yaitu (AS Pabla, 199):

1) Pemasangan luar

Transformator dapat dipasang dengan salah satu cara berikut ini :

a) Pemasangan langsung $\quad \mid$

Langsung diklem dengan klem yang cocok dengan tiang.Cara ini cukup baik untuk transformator kecil sampai $25 \mathrm{kVA}$ saja.

b) Pemasangan pada tiang $\mathrm{H}$

Transformator dipasang dengan lengan silang yang dipasang diantara dua tiang dan diikat erat. Cara ini sesuai untuk transformator berkapasitas hingga 200 $\mathrm{kVA}$.

c) Pemasangan pada platform

Sebuah platform dibuat pada suatu struktur yang terdiri dari 4 (empat) tiang untuk menentukan transformator. Cara ini dianjurkan pada tempat - tempat yang berbahaya bila menempatkan transformator di atas tanah.

2) Pemasangan di lantai

Cara ini cocok untuk semua ukuran transformator. Permukaan lantai harus lebih tinggi dari sekelilingnya guna mengatasi banjir. Sebaiknya dibuat dari pondasi beton. Jika sejumlah transformator ditempatkan berdekatan sekali, maka harus dibuatkan dinding pemisah yang tahan api untuk mengurangi kerusakan yang timbul jika terjadi kecelakaan atas salah satu transformator 
tersebut. Di sekeliling transformator yang terpasang di lantai harus direncanakan adanya aliran udara bebas pada semua transformator.Jika mungkin, transformator yang terpasang di luar harus dilindungi terhadap sinar matahari secara langsung.

3) Pemasangan dalam

Bangunan untuk rumah transformator harus cukup luar agar dapat bebas masuk dari setiap sisi dan cukup tinggi agar dapat membuka transformator tersebut. , tata laksana pengelolaan anggaran, akuntansi dan pengelolaan material yang berhubungan dengan manajemen pemeliharaan agar berpedoman kepada.Jarak minimum transformator dari sisi dinding dianggap memadai/memuaskan.

\section{Definisi Manajemen Pemeliharaan}

Secara umum, manajemen pemeliharaan yang dimaksud di sini adalah suatu proses kegiatan pemeliharaan yang meliputi rangkaian tahapan-tahapan kerja yang teratur secara sistematis mulai pada fase perencanaan, pelaksanaan hingga pada fase pengendalian dan evaluasi.

Bentuk-bentuk pemeliharaan yang sering ditemui di lingkungan sehari-hari, antara lain :

\section{a) Pemeliharaan Preventif}

Pemeliharaan preventif adalah bentuk pemeliharaan yang mencegah terjadinya kerusakan peralatan secara tiba-tiba dengan mempertahankan unjuk kerja jaringan agar selalu beroperasi dengan keandalan dan efisiensi yang tinggi.

\section{b) Pemeliharaan Korektif}

Pemeliharaan korektif dapat dibedakan dalam dua kegiatan, yaitu :terencana dan tidak terencana.

Kegiatan terencana diantaranya adalah pekerjaan perubahan/penyempurnaan yang dilakukan pada jaringan untuk memperoleh keandalan yang baik (dalam batas pengertian operasi) tanpa mengubah kapasitas semula.Sedang kegiatan yang tidak terencana misalnya mengatasi kerusakan peralatan atau gangguan.

\section{c) Pemeliharaan Khusus}

Pemeliharaan khusus atau disebut juga pemeliharaan darurat adalah pekerjaan pemeliharaan untuk memperbaiki jaringan yang rusak akibat force majeure seperti bencana alam, kebakaran, huru hara dan sebagainya.

\section{Ruang Lingkup dan Tujuan Pemeliharaan}

a) Ruang Lingkup Pemeliharaan

Dalam pemeliharaan transformator dan jaringan distribusi, tata laksana pengelolaan anggaran, akuntansi dan pengelolaan material yang berhubungan dengan manajemen pemeliharaan agar berpedoman kepada surat edaran direksi atau surat edaran yang berlaku.

b. Tujuan Pemeliharaan

Pemeliharaan transformator dan jaringan distribusi memiliki beberapa tujuan, antara lain :

1) Menjaga dan merawat agar peralatan/komponen dapat dioperasikan secara optimal berdasarkan spesifikasinya sehingga sesuai dengan umur ekonomisnya,

2) Menjamin agar peralatan atau komponen tetap berftmgsi dengan baik untuk menyalurkan energi listrik dan pusat listrik sampai ke konsumen (pelanggan / masyarakat).

\section{HASIL DAN PEMBAHASAAN}

\section{Perhitungan Hasil Pengukuran}

1) Untuk trafo $3 \phi$

$\mathrm{P}_{\mathrm{R}}=\mathrm{V}_{\mathrm{N}} \times \mathrm{I}_{\mathrm{R}}$

$$
=224 \times 109
$$

$=24416 \mathrm{Va}$

$=24,416 \mathrm{KVA}$

$\mathrm{P}_{\mathrm{S}}=\mathrm{VN} \times \mathrm{Is}$

$=224 \times 138$

$=30912 \mathrm{VA}$

$=30,912 \mathrm{KVA}$

$\mathrm{PT}=\mathrm{V}_{\mathrm{N}} \times \mathrm{I}_{\mathrm{T}}$

$=224 \times 102$

$=22848 \mathrm{VA}$

$=22,848 \mathrm{KVA}$

$\mathrm{P}_{\mathrm{tot}}=\mathrm{P}_{\mathrm{R}}+\mathrm{P}_{\mathrm{S}}+\mathrm{P}_{\mathrm{T}}$

$=24,416+30,912+22,848$

$=78,176$ 
Penentuan kapasitas trafo

Kapasitas trafo $=Z$ Daya terpasang $+30 \%$ dari

Daya terpasang

$$
\begin{aligned}
& =78,1764-23,452 \\
& =101,628 \mathrm{KVA}
\end{aligned}
$$

Jadi daya yang digunakan adalah 101,628KVA, maka trafo yang layak digunakan adalah trao yang berkapasitas 150 KVA.

2) Untuk trafo $1 \phi$

$$
\begin{aligned}
& \mathrm{P}=\mathrm{V} \\
& \begin{array}{llll}
= & 206 & \mathrm{x} & 115
\end{array} \\
& =23690
\end{aligned}
$$

Penentuan kapasitas trafo

Kapasitas trafo $=\Sigma$ Daya terpasang + $30 \%$ dari Daya terpasang

$$
\begin{aligned}
& =23,69+7,107 \\
& =30,797 \mathrm{KVA}
\end{aligned}
$$

Jadi daya yang digunakan adalah 30,797 KVA, maka trafo yang layak digunakan adalah trafo yang berkapasitas 50 KVA.

Berdasarkan tabel 1. KHA terus menerus untuk kabel tanah berinti tunggal, berpenghantar aluminium, berselubung dan berisolasi PVC, dipasang pada sistem arus searah dengan tegangan kerja maksimum 1,8 $\mathrm{kV}$,

dengan tegangan pengenal $0,6 / 1 \mathrm{kV}(1,2$ $\mathrm{kV}$ ), suhu keliling $30^{\circ} \mathrm{C}$.

gangguan dari pada tindakan reprensif dalam mengatasi gangguan. Untuk itu diperlukan beberapa hal, yaitu :

1) Komitmen dan peran serta pimpinan cabang dan semua unit yang terkait dalam pelaksanaan pemeliharaan tersebut.

2) Informasi atau data aset Jaringan distribusi.Data aset Jaringan distribusi yang diperlukan untuk menyusun program dan memprioritaskan pemeliharaan fisik Jaringan, misalnya : nama peralatan, tipe atau jenis peralatan, spesifikasi atau merek, tahun pembuatan, tahun operasi dan jumlah atau panjang aset dan sebagainya yang dianggap penting bagi pengelolaan Jaringan distribusi, disamping itu buku petunjuk atau manual dari pabrik pembuat perlu disimpan dan dikelolah secara baik sebagai bagian dari data aset Jaringan,

3) Peningkatan kemampuan petugas pelaksana pemeliharaan.

Program pemeliharaan harus dilaksanakan oleh petugas yang terampil dalam bidangnya. Oleh karena itu, peningkatan kemampuan petugas pelaksana, baik keterampilan teknis maupun manajemen harus dilaksanakan secara baik dan berkesinambungan. Untuk perencanaan karir, kaderisasi petugas juga harus dilakukan, disamping itu pembinaan terhadap mitra kerja (kontraktor listrik/KUD) yang menangani pemeliharaan merupakan kewajiban PLN.

4) Pemeliharaan transformator dan jaringan distribusi yang dilaksanakan dengan mengoptimalkan sumber daya manusia yang dimiliki PLN.

Pelaksanaan pekerjaan pemeliharaan agar diupayakan secara swakelolah yaitu dilaksanakan sendiri oleh petugas pemeliharaan PLN. Pekerjaan pendukung yang tidak memiliki keahlian atau pekerjaan yang memerlukan tenaga kasar dapat diserahkan pada pihak ketiga. Dalam kondisi kurangnya petugas pemeliharaan, maka pekerjaan pemeliharaan seluruh atau sebagian dapat dilaksanakan oleh pihak ketiga dengan supervise oleh PLN. Sebagai tolak ukur keberhasilan pemeliharaan dapat dilihat dari beberapa aspek, antara lain :

a) Berkurangnya jumlah gangguan

b) Berkurangnya jumlah jurusan yang bertegangan di bawah.

Berdasarkan tabel 2. KHA terus menerus untuk kabel tanah berinti tunggal, berpenghantar aluminium, berselubung dan berisolasi PVC, dipasang pada sistem arus searah dengan tegangan kerja maksimum 1,8 $\mathrm{kV}$, serta untuk kabel tanah berinti dua, tiga dan empat berpenghantar aluminium, berisolasi dan berselubung PVC yang dipasang pada sistem arus fasa tiga dengan tegangan pengenal $0,6 / 1 \mathrm{kV}(1,2 \mathrm{kV})$, suhu keliling 30 ${ }^{\circ} \mathrm{C}$. 
Tabel 1. KHA Tembaga

\begin{tabular}{|c|c|c|c|c|c|c|c|}
\hline & & & & KHA te & us meneru & & \\
\hline & Luas penrampang & Berinti & tunggal & Beril & ti dua & Berinti ti & dan empat \\
\hline & & di tanah & di udara & di tanah & di udara & di tanah & di udara \\
\hline & 1,5 & 40 & 26 & 31 & 20 & 26 & 18,5 \\
\hline & 2,5 & 54 & 35 & 41 & 27 & 34 & 25 \\
\hline & 4 & 70 & 46 & 54 & 37 & 44 & 34 \\
\hline & 6 & 90 & 58 & 68 & 48 & 56 & 43 \\
\hline NYY & 10 & 122 & 79 & 92 & 66 & 75 & 60 \\
\hline NYBY & 16 & 160 & 105 & 121 & 89 & 98 & 80 \\
\hline NYFGbY & 25 & 206 & 140 & 153 & 118 & 128 & 106 \\
\hline NYRGbY & 35 & 249 & 174 & 187 & 145 & 157 & 131 \\
\hline NYCY & 50 & 296 & 212 & 222 & 176 & 185 & 159 \\
\hline NYCWY & 70 & 365 & 269 & 272 & 224 & 228 & 202 \\
\hline NYSY & 95 & 438 & 331 & 328 & 271 & 275 & 244 \\
\hline NYCEY & 120 & 499 & 386 & 375 & 314 & 313 & 282 \\
\hline NYSEY & 150 & 561 & 442 & 419 & 361 & 353 & 324 \\
\hline NYHSY & 185 & 637 & 511 & 475 & 412 & 399 & 371 \\
\hline NYKY & 240 & 743 & 612 & 550 & 484 & 464 & 436 \\
\hline NYKBY & 300 & 843 & 707 & 525 & 590 & 524 & 481 \\
\hline NYKFGY & 400 & 986 & 859 & 605 & 710 & 600 & 560 \\
\hline NYKRGbY & 500 & 1125 & 1000 & - & - & - & - \\
\hline
\end{tabular}


Tabel 2. KHA Aluminium

\begin{tabular}{|c|c|c|c|c|c|c|c|}
\hline & \multirow{3}{*}{$\begin{array}{l}\text { Luas penampang } \\
\text { nominal } \mathrm{mm}^{2-}\end{array}$} & \multicolumn{6}{|c|}{ KHA terus menerus $\mathrm{A}$} \\
\hline & & \multicolumn{2}{|c|}{ Berinti tunggal } & \multicolumn{2}{|c|}{ Berinti dua } & \multicolumn{2}{|c|}{ Berinti tiga dan empat } \\
\hline & & di tanah & di udara & di tanah & di udara & di tanah & di udara \\
\hline & 4 & 45 & 36 & 36 & 29 & 32 & 26 \\
\hline & 6 & 57 & 45 & 45 & 37 & 40 & 34 \\
\hline & 10 & 76 & 62 & 61 & 51 & 53 & 46 \\
\hline & 16 & 102 & 82 & 79 & 70 & 69 & 62 \\
\hline & 25 & 134 & 125 & 102 & 91 & 93 & 83 \\
\hline NAYY & 35 & 180 & 145 & 125 & 113 & 111 & 102 \\
\hline NYBY & 50 & 215 & 176 & 147 & 138 & 133 & 124 \\
\hline NYFGbY & 70 & 265 & 224 & 178 & 174 & 165 & 158 \\
\hline NYRGbY & 95 & 319 & 271 & 218 & 210 & 198 & 190 \\
\hline NYCY & 120 & 683 & 314 & 245 & 244 & 227 & 221 \\
\hline NYCWY & 150 & 409 & 361 & 280 & 281 & 254 & 252 \\
\hline NYSY & 185 & 464 & 412 & 316 & 320 & 290 & 289 \\
\hline NYCEY & 240 & 543 & 484 & 369 & 378 & 341 & 339 \\
\hline NYSEY & 300 & 615 & 548 & 414 & 460 & 387 & 377 \\
\hline \multirow[t]{2}{*}{ YHSY } & 400 & 719 & 666 & 481 & 550 & 446 & 444 \\
\hline & 500 & 821 & 776 & - & - & - & - \\
\hline
\end{tabular}




\section{Strategi Pemeliharaan}

Pemeliharaan terhadap transformator dan Jaringan distribusi dilaksanakan secara proaktif dengan mengutamakan tindakan preventif yang bertujuan untuk mencegah terjadinya gangguan dari pada tindakan reprensif dalam mengatasi gangguan.

\section{PENUTUP}

\section{Simpulan}

Berdasarkan hasil studi yang telah dilakukan di PT. PLN (Persero) Cabang Pinrang, maka dapat kami tankap beberapa kesimpulan yaitu :

1) Jaringan distribusi yang digunakan pada PT. PLN (Persero) Cabang Pinrang terdiri dari saluran distribusi primer, transformator distribusi dan saluran distribusi sekunder. Jaringan distribusi ini digunakan untuk mendistribusikan energi listrik ke seluruh masyarakat Kabupaten Pinrang.

2) Kapasitas dari suatu transformator distribusi untuk 3 fase dan 1 fase ditentukan oleh jumlah beban yang dilayani ditambahkan dengan perkembangan beban dikemudian hari.

3) Sistem pemeliharaan yang dilakukan pada Jaringan distribusi dan transformator pada PT. PLN (Persero) Cabang Pinrang dilakukan secara rutin dan proaktif dengan mengutamakan tindakan preventif yang bertujuan untuk mencegah terjadinya gangguan dari pada tindakan reprensif dalam mengatasi terjadinya gangguan.

\section{Saran}

1) Untuk memperoleh ketelitian data hasil pencatatan pada setiap gardu distribusi diperlukan keseriusan dalam mengamati hasil pendataan pada alat ukur gardu distribusi.

2) Dibutuhkan studi yang lebih ianjut demi kesempurnaan isi penulisan ini, khususnya dalam upaya peningkatan pelayanan tenaga listrik kepada masyarakat di masa sekarang hingga di masa yang akan datang. 